\title{
TU/e EmHOONEN

\section{Heat transfer during growth of a boiling bubble on the wall in turbulent channel flow}

\section{Citation for published version (APA):}

Kuerten, J. G. M., Geld, van der, C. W. M., \& Esch, van, B. P. M. (2007). Heat transfer during growth of a boiling bubble on the wall in turbulent channel flow. In Advances in Turbulence XI - Proceedings of the 11th EUROMECH European Turbulence Conference (pp. 277-279). Springer. https://doi.org/10.1007/978-3-54072604-3_87

DOI:

10.1007/978-3-540-72604-3_87

Document status and date:

Published: 01/01/2007

\section{Document Version:}

Accepted manuscript including changes made at the peer-review stage

\section{Please check the document version of this publication:}

- A submitted manuscript is the version of the article upon submission and before peer-review. There can be important differences between the submitted version and the official published version of record. People interested in the research are advised to contact the author for the final version of the publication, or visit the $\mathrm{DOI}$ to the publisher's website.

- The final author version and the galley proof are versions of the publication after peer review.

- The final published version features the final layout of the paper including the volume, issue and page numbers.

Link to publication

\section{General rights}

Copyright and moral rights for the publications made accessible in the public portal are retained by the authors and/or other copyright owners and it is a condition of accessing publications that users recognise and abide by the legal requirements associated with these rights.

- Users may download and print one copy of any publication from the public portal for the purpose of private study or research.

- You may not further distribute the material or use it for any profit-making activity or commercial gain

- You may freely distribute the URL identifying the publication in the public portal.

If the publication is distributed under the terms of Article 25fa of the Dutch Copyright Act, indicated by the "Taverne" license above, please follow below link for the End User Agreement:

www.tue.nl/taverne

Take down policy

If you believe that this document breaches copyright please contact us at:

openaccess@tue.nl

providing details and we will investigate your claim. 


\title{
Heat Transfer during Growth of a Boiling Bubble on the Wall in Turbulent Channel Flow
}

\author{
J.G.M. Kuerten, C.W.M. van der Geld and B.P.M. van Esch \\ Department of Mechanical Engineering, Technische Universiteit Eindhoven, \\ P.O.Box 513, NL-5600 MB Eindhoven, The Netherlands j.g.m.kuerten@tue.nl
}

\section{Introduction}

Heat transfer to a growing boiling bubble at a plane wall is complicated because of a microlayer between vapor and solid, convection and diffusion and the interaction of flow and heat transfer in the wall. However, typical bubble growth histories [1] and heat flow rate histories [2] are known from experiments. This allows to decouple the growth of a vapor bubble from its effect on temperatures and to consider the bubble as a distribution of heat sinks. One of the important issues to be addressed is the extent to which turbulent fluid velocity fluctuations affect bubble growth. Here, this is investigated by means of DNS of turbulent flow and heat in the presence of a bubble. The geometry is a plane channel, where on both walls a heat flux is supplied. The temperature is split into a periodic part and a part which varies linearly with streamwise coordinate and matches the energy supplied at the walls.

\section{Numerical method}

The Navier-Stokes equation and the heat equation for the temperature of the fluid and of the wall are solved by a spectral method, consisting of a FourierGalerkin method in the two periodic directions and a Chebyshev collocation method in the wall-normal direction. Integration in time is second-order accurate. A vapor bubble is created at a position on the wall where the temperature first exceeds a preset value. From that time onwards the bubble starts growing and subtracts energy from both fluid and wall, in a ratio that is prescribed (2:1) as measured in a dedicated set-up in our laboratory [2]. Also the bubble radius history is based on measurements. The bubble is simulated by heat sources of equal strength distributed over a line in $y$-direction, that ends where the top of the bubble at that time is situated. In the wall, equal heat sinks at three neighboring collocation points in $y$-direction are employed. 


\section{Results and analysis}
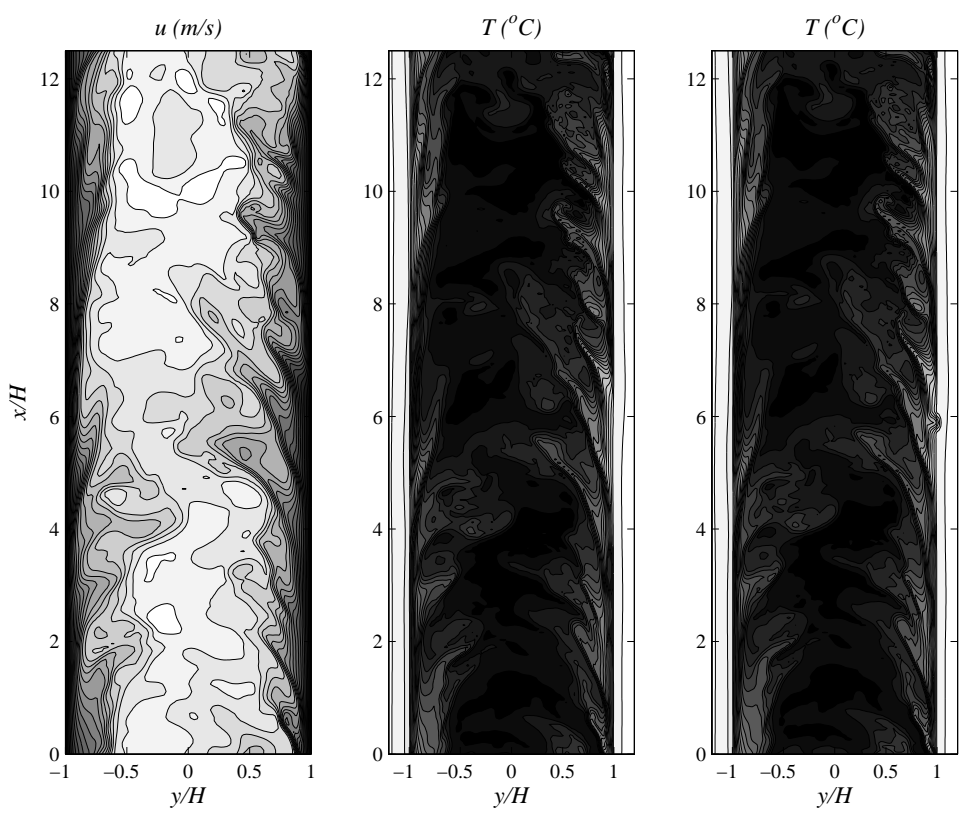

Fig. 1. Velocity and temperature fields at bubble inception in a cross-section of the channel flow (left). Temperature field at bubble detachment (right), with cooling near the bubble clearly visible in the center of the channel wall on the right.

The results show that during the time of growth of a bubble the velocity and temperature near the bubble site hardly change, see Fig.1, and that the velocity length scales exceed those of the temperature, because of the Prandtl number exceeding 1. Moreover, where velocity is low, temperature is high. Temperature variations at the bubble site due to convection are negligible, and diffusion would control heat transfer to the bubble interface if it would be stationary. Figure 2 shows that the liquid near the bubble is cooled by heat consumed for evaporation, whereas further away temperature is constant during bubble growth. Diffusion of heat to the bubble is barely visible in this $(y$-)direction, since penetration depth due to diffusion is too small. The isotherms in the fluid are shifted because of the growth of the bubble. The isotherms in the wall are shifted because of heat extraction for $y / H<1.02$ and because of diffusion of heat further away in the wall. Temporal changes in temperature due to diffusion of heat are controlled by the Fourier number, $F_{o} \stackrel{\text { def }}{=} \alpha t / L$. Here, $L$ is a typical length scale, with $\alpha$ the heat diffusion constant, $\lambda /\left(\rho c_{p}\right)$, and $t$ time. Both $\alpha$ and $\lambda$ are about 20 times as larger in the wall than in the fluid. The diffusion penetration depth at certain time for 


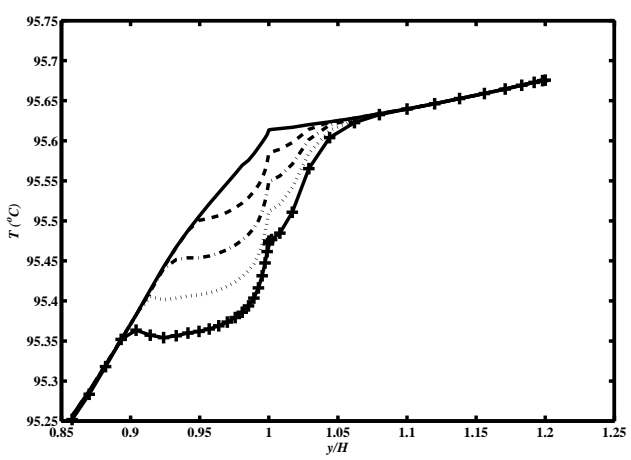

Fig. 2. History of temperatures at the line normal to the wall at the bubble center (at $y=H$ ). Solid line is at bubble inception, bottom line at bubble detachment, other lines at equidistant time steps in between.

a given isotropic heat sink located at the wall can be estimated to be about $3 \sqrt{4 \alpha t}$, and diffusion is therefore clearly visible in the wall. Note that in our simulation of a bubble, twice as much heat is taken from the fluid than from the wall. The temporal variation of temperatures near the bubble site and near the wall is relatively small since the bubble was initiated at a spot of high temperature that corresponds to a low velocity. If the thermal properties of the fluid and the wall would be selected differently, such that the $\alpha$-ratio would change, similar observations could be made. However, the ratio 2 of heat taken from the fluid to that taken from the wall would probably need to be selected differently as well, and no data exist to support the choice. If the wall thickness would be decreased to about the diffusion penetration depth in the wall, a further spread in flow direction of isotherm changes would be found.

The main conclusion is that turbulent fluctuations hardly affect heat transfer to a boiling bubble when bubble-bubble interaction at neighboring sites can be ignored. This observation does not depend on the Reynolds number, but turbulent stresses might affect the forces involved in bubble detachment.

\section{References}

1. C.W.M. van der Geld, W.G.J. van Helden, P.G.M.T. Boot: On the effect of the temperature boundary condition on single bubble detachment in flow boiling. In: Convective flow boiling, ed by J.C. Chen, 149-154, 1996.

2. M. Kovačević, C.W.M. van der Geld: Single bubble growth in saturated flow boiling on a constant wall temperature surface in uniform approaching flow, International Topical Team Workshop on Two-Phase Systems for Ground and Space Applications, Brussels, September, 2006. 